\title{
Synthesis of High-Stability Acidic $\beta /$ Al-MCM-41 and the Catalytic Performance for the Esterification of Oleic Acid
}

\author{
Zhiping Wang, Shitao Yu* \\ College of Chemical Engineering, Qingdao University of Science and Technology, Qingdao, China \\ Email: *wangzhiping@qust.edu.cn
}

How to cite this paper: Wang, Z.P. and $\mathrm{Yu}$ S.T. (2016) Synthesis of High-Stability Acidic $\beta /$ Al-MCM-41 and the Catalytic Performance for the Esterification of Oleic Acid. Advances in Chemical Engineering and Science, 6, 305 315. http://dx.doi.org/10.4236/aces.2016.64031

Received: May 9, 2016

Accepted: August 14, 2016

Published: August 17, 2016

Copyright $\odot 2016$ by authors and Scientific Research Publishing Inc. This work is licensed under the Creative Commons Attribution International License (CC BY 4.0).

http://creativecommons.org/licenses/by/4.0/

\begin{abstract}
$\beta / \mathrm{Al}-\mathrm{MCM}-41$ molecular sieve was synthesized and used to catalyze the esterification of oleic acid with short chain alcohols such as methanol, ethanol, isopropanol and isobutanol to obtain biodiesel. The results indicated that $\beta / \mathrm{Al}-\mathrm{MCM}-41$ exhibited the excellent catalytic activity and stability, which was obviously superior to traditional Al-MCM-41. The relationship between acidity and catalytic activity was in detail examined by $\mathrm{NH}_{3}$-TPD and Py-FTIR. Moreover, the kinetics of esterification of oleic acid with methanol showed that the average reaction order $n$ was 1.97 and that activation energy was $50.01 \mathrm{~kJ} / \mathrm{mol}$.
\end{abstract}

\section{Keywords}

Kinetics, Esterification, Molecular Sieve, $\beta /$ Al-MCM-41

\section{Introduction}

With the increasingly serious in the energy shortage and environmental problems, biodiesel has been widely studied as a kind of non toxic fuel for renewable and easily biodegradable. Among all kinds of biodiesels, fatty acid ester, obtained from the esterification of oleic acid with alcohol, has received greater attention using as biofuel in recent years [1] [2]. This kind of biodiesel has the advantages of ready raw materials, simple production process and high calorific value [3]-[5]. In industry, liquid sulfuric acid was used as catalyst to produce fatty acid ester [6]. However, the traditional catalysts have shortcomings including serious corrosion of equipment, complicated separation procedures, serious environmental problems and byproducts because of strong oxidizing property. These greatly restricted the wide application of fatty acid ester. Therefore, 
choosing the reasonable catalyst is the key to promote the wide application of fatty acid ester. To meet the requirements of low carbon environmental protection and sustainable development, the catalyst should have the characteristics of high efficiency, recoverable and low corrosion. Therefore, solid acid is an important research direction used instead of the liquid acid to overcome the defects above mentioned [7] [8].

For large molecular reaction is catalyzed by traditional microporous molecular sieves such as Y, Beta and ZSM-5, the large molecular reactant is not easy to enter the inner surface, while most reacts on the outer surfaces, so the activity and selectivity are affected [9]. Mesoporous molecular sieves such as MCM-41 possess a hexagonal arrangement of uniformly sized unidimensional mesoporous and both ends opened, 1.5 $10 \mathrm{~nm}$ pore size distribution and large surface area so that it shows obvious superiority for reactions of large substrates [10]. Although MCM-41 has many merits, its weak acidity together with poor hydrothermal stability and other defects limits its application greatly [11]. To overcome the limitations of microporous and mesoporous molecular sieve, in recent years, the structure of microporous molecular sieve was introduced into the mesoporous molecular sieve. The mosoporous material was transformed into a crystalline structure. At the same time, the metal ions producing acid center was introduced into the skeleton. The high acidity and high hydrothermal stability of mesoporous material have been prepared [12]-[17]. The framework is highly crystalline and exhibits a remarkably catalytic activity and stability with environment friendly for many reactions [18]-[24].

In present paper, we reported the preparation and characterization of the molecular sieves $\beta / \mathrm{Al}-\mathrm{MCM}-41$, and the application in the esterification of oleic acid with short chain alcohols. The activity, acidity and stability of the catalyst were investigated as well. A kinetic model for the esterification was established and the reaction kinetics was studied. To the best of our knowledge, this is the first report on the use of $\beta / \mathrm{Al}$ MCM-41 molecular sieves as catalysts for the preparation of biodiesel.

\section{Experimental}

\subsection{Regent and Equipment}

All materials, including oleic acid, methanol, ethanol, isopropyl alcohol, isobutyl alcohol, sulfuric acid, tetraethyl ammonium hydroxide, sodium aluminate, hexadecyltrimethyl ammonium bromide (CTAMBr) and sodium hydroxide were purchased from Aldrich, and all materials were used directly after drying without further purification.

$\mathrm{X}$-ray powder diffraction patterns of the samples were obtained on a XD-610 instrument using monochromatic $\mathrm{Cu} \mathrm{K} \alpha$ radiation. It was operated at $30 \mathrm{kV}$ and $20 \mathrm{~mA}$ with a step width of $0.02^{\circ}$, diffraction region of $2 \theta=1^{\circ}-10^{\circ}$ and a scan speed of $2^{\circ} / \mathrm{min}$. All Py-FTIR spectra were recorded with a Nicolet NEXUS470 FTIR spectrometer in the range of $4000-500 \mathrm{~cm}^{-1}$. The samples were pretreated for $2 \mathrm{~h}$ at $400^{\circ} \mathrm{C}$ and less than $10^{-3} \mathrm{~Pa}$ then reduced to room temperature. Pyridine was adsorbed onto the samples for $1 \mathrm{~h}$ and desorbed for $1 \mathrm{~h}$ under $2 \mathrm{~Pa}$. The $\mathrm{NH}_{3}$-TPD was performed by a DLUT-1 automatic temperature programmed desorption apparatus. The sample is treated at $500^{\circ} \mathrm{C}$ in nitrogen flow for $120 \mathrm{~min}$. Then the temperature is reduced to $120^{\circ} \mathrm{C}$ and keeps the 
sample in a flow of $\mathrm{NH}_{3}$ for $60 \mathrm{~min}$. The amount of desorbed $\mathrm{NH}_{3}$ is determined after heating the sample up to $600^{\circ} \mathrm{C}$ (heating rate of $10^{\circ} \mathrm{C} \mathrm{min}{ }^{-1}$ ).

The aim products were analyzed by TRACE-GC-MS chromatographer with an FID and a DB-17MS phenyl methyl siloxanes capillary column $(30 \mathrm{~m} \times 0.25 \mathrm{~mm})$. The temperature of injector and transference line were maintained constant at $270^{\circ} \mathrm{C}$. The temperature of the furnace was maintained at $180^{\circ} \mathrm{C}$ for $30 \mathrm{~min}$. The carrier gas was helium. The injection volume was $0.1 \mu \mathrm{L}$.

\subsection{Catalyst Preparation}

$\beta /$ Al-MCM-41 was synthesized by stepwise crystallization method. First zeolite precursors solution with zeolite beta primary structure units were prepared according to a certain molar ratio of $\mathrm{Al}_{2} \mathrm{O}_{3}: 60 \mathrm{SiO}_{2}: 2.5 \mathrm{Na}_{2} \mathrm{O}: 22$ TEAOH:800 $\mathrm{H}_{2} \mathrm{O}$, then transferred the mixture into an autoclave aging for $4 \mathrm{~h}$ at $140^{\circ} \mathrm{C}$ to get a clear solution. The obtained zeolite precursors solution was added to $\mathrm{CTAMBr}$ solution according to a molar ratio of 1:5 Si:CTAMBr, mixed and agitated slowly for $30 \mathrm{~min}$, regulated at $\mathrm{pH}=8-9$ using $5 \mathrm{~mol} / \mathrm{L}$ sulfuric acid, stirred at $260 \mathrm{rpm}$ for $1 \mathrm{~h}$ under the condition of normal temperature after adding alcohol, then the mixed solution was crystallized at $110^{\circ} \mathrm{C}$ for $24 \mathrm{~h}$, vacuum filtrated, washed, dried and calcined for $8 \mathrm{~h}$ at $550^{\circ} \mathrm{C}$ to prepare $\beta / \mathrm{Al}-\mathrm{MCM}-41$.

\subsection{Esterification of Oleic Acid}

The catalyst was added into a mixture of oleic acid with either methanol, ethanol, isopropanol or isobutanol, and the reaction was carried out under autogenous pressure and intensive electronic stirring in an autoclave at the reaction temperature for $2-10 \mathrm{~h}$. The results were calculated according to neutralization titration. The reaction has been repeated for three times and the results are of excellent stability. The esterification rate $/ \%=(1$-acid value of esterified product/acid value of reactant $) \times 100 \%$.

Reaction equation:

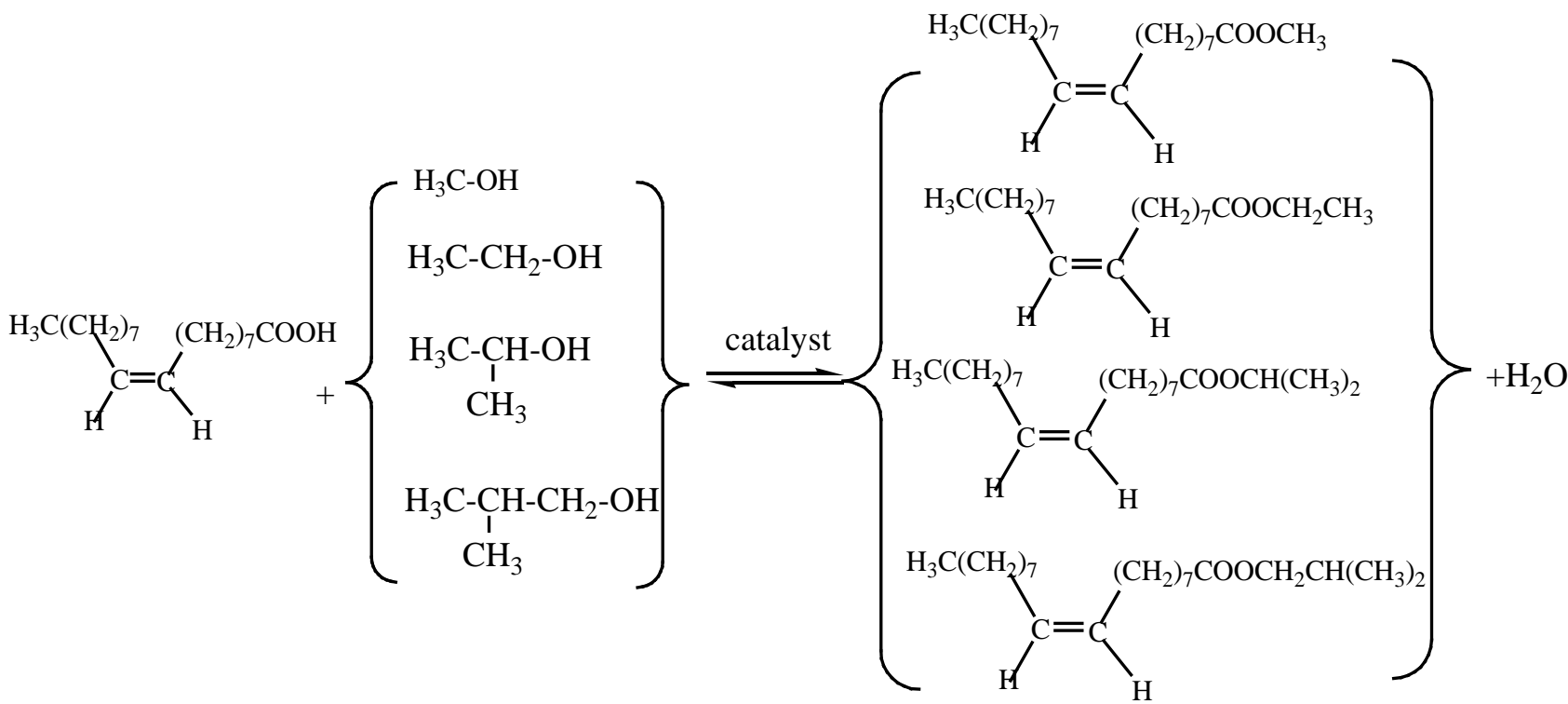




\section{Results and Discussion}

\subsection{Choice of Catalysts}

The activities of different catalysts were investigated on the esterification of oleic acid. The detailed results are shown in Table 1. From No. 1 - 2, acidic catalysts are suitable for the esterification of oleic acid with methanol, the yield of methyl oleate was increased significantly. The catalytic effect was unsatisfactory catalyzed by pure $\beta$ and pure Al-MCM-41 (No. 3 - 5). While sulfuric acid $\left(\mathrm{H}_{2} \mathrm{SO}_{4}\right)$, as the higher catalytic activity catalyst for the esterification of oleic acid, has many disadvantages, such as too large amount of catalyst usage, serious corrosion of equipments, complicated separation procedures, environmental problems, and by-products. It can be seen that $\beta / \mathrm{Al}-\mathrm{MCM}-41$ exhibited excellent catalytic activity, the conversion of oleic acid can reach about $70 \%$, which obviously superior to Al-MCM-41. Use $\beta / \mathrm{Al}-\mathrm{MCM}-41$ to catalyze the esterification of oleic acid with ethanol, isopropanol and isobutanol, the yields of ester were higher (No. 6 - 11). The high catalytic activity and stability in the esterification of the catalyst was discussed.

The $\mathrm{NH}_{3}$-TPD profiles of $\beta / \mathrm{Al}-\mathrm{MCM}-41$ and Al-MCM-41 is shown in Figure 1. It can be seen that the both samples have a very strong peak at low temperature about $100^{\circ} \mathrm{C}-200^{\circ} \mathrm{C}$ and a middle strong peak at high temperature about $700^{\circ} \mathrm{C}-800^{\circ} \mathrm{C}$, belonging to poor acid and strong acid, respectively. By quantitative analysis, the amount of the poor acid and strong acid for $\beta / \mathrm{Al}-\mathrm{MCM}-41$ are obviously more than Al-MCM-41. This is maybe the key reason why $\beta / \mathrm{Al}-\mathrm{MCM}-41$ is of high catalytic performance.

Table 1. Effect of different catalysts on reaction results ${ }^{\mathrm{a}}$.

\begin{tabular}{|c|c|c|c|c|c|}
\hline No. & Catalyst & Alcohol & $\begin{array}{l}\text { Acid value of } \\
\text { reactant } / \mathrm{mg}^{-1} \mathrm{~g}^{-1}\end{array}$ & $\begin{array}{c}\text { Acid value } \\
\text { of esterified } \\
\text { product } / \mathrm{mg}^{-1} \mathrm{~g}^{-1}\end{array}$ & $\begin{array}{c}\text { Esterification } \\
\text { rate } / \%\end{array}$ \\
\hline 1 & --- & $\mathrm{CH}_{3} \mathrm{OH}$ & $84.2 \pm 0.6$ & $69.8 \pm 0.3$ & $17.1 \pm 0.3$ \\
\hline 2 & $\mathrm{H}_{2} \mathrm{SO}_{4}(98 \mathrm{wt} \%)$ & $\mathrm{CH}_{3} \mathrm{OH}$ & $84.3 \pm 0.4$ & $14.3 \pm 0.6$ & $83.0 \pm 0.5$ \\
\hline 3 & $\beta$ & $\mathrm{CH}_{3} \mathrm{OH}$ & $84.5 \pm 0.5$ & $45.9 \pm 0.6$ & $45.7 \pm 0.4$ \\
\hline 4 & Al-MCM-41 & $\mathrm{CH}_{3} \mathrm{OH}$ & $84.3 \pm 0.4$ & $49.9 \pm 0.5$ & $40.8 \pm 0.6$ \\
\hline 5 & $\beta / \mathrm{Al}-\mathrm{MCM}-41$ & $\mathrm{CH}_{3} \mathrm{OH}$ & $84.2 \pm 0.5$ & $21.2 \pm 0.4$ & $74.8 \pm 0.5$ \\
\hline 6 & $\mathrm{H}_{2} \mathrm{SO}_{4}(98 \mathrm{wt} \%)$ & $\mathrm{CH}_{3} \mathrm{CH}_{2} \mathrm{OH}$ & $84.6 \pm 0.3$ & $29.5 \pm 0.4$ & $65.1 \pm 0.6$ \\
\hline 7 & $\beta / \mathrm{Al}-\mathrm{MCM}-41$ & $\mathrm{CH}_{3} \mathrm{CH}_{2} \mathrm{OH}$ & $84.5 \pm 0.2$ & $36.7 \pm 0.4$ & $56.6 \pm 0.4$ \\
\hline 8 & $\mathrm{H}_{2} \mathrm{SO}_{4}(98 \mathrm{wt} \%)$ & $\left(\mathrm{CH}_{3}\right)_{2} \mathrm{CHOH}$ & $84.2 \pm 0.4$ & $32.9 \pm 0.6$ & $60.9 \pm 0.4$ \\
\hline 9 & $\beta / \mathrm{Al}-\mathrm{MCM}-41$ & $\left(\mathrm{CH}_{3}\right)_{2} \mathrm{CHOH}$ & $84.3 \pm 0.4$ & $40.7 \pm 0.4$ & $51.7 \pm 0.3$ \\
\hline 10 & $\mathrm{H}_{2} \mathrm{SO}_{4}(98 \mathrm{wt} \%)$ & $\left(\mathrm{CH}_{3}\right)_{2} \mathrm{CHCH}_{2} \mathrm{OH}$ & $84.3 \pm 0.5$ & $40.5 \pm 0.5$ & $52.0 \pm 0.4$ \\
\hline 11 & $\beta / \mathrm{Al}-\mathrm{MCM}-41$ & $\left(\mathrm{CH}_{3}\right)_{2} \mathrm{CHCH}_{2} \mathrm{OH}$ & $84.5 \pm 0.3$ & $47.7 \pm 0.4$ & $43.6 \pm 0.3$ \\
\hline
\end{tabular}

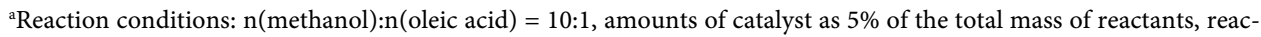
tion temperature $120^{\circ} \mathrm{C}$, reaction time $8 \mathrm{~h}$. 


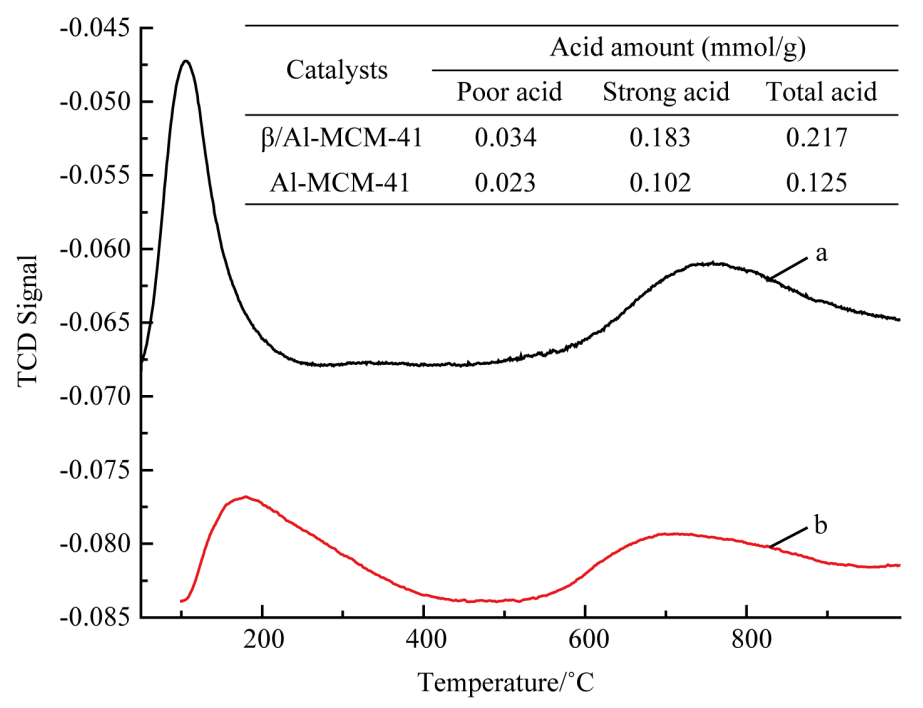

Figure 1. $\mathrm{NH}_{3}$-TPD of $\beta /$ Al-MCM-41 and Al-MCM-41. (a) $\beta /$ Al-MCM-41, (b) Al-MCM-41.

The Py-FTIR spectrum of $\beta / \mathrm{Al}-\mathrm{MCM}-41$ and Al-MCM-41 is shown in Figure 2. The presence of the band at $1596 \mathrm{~cm}^{-1}$ was associated with Bronsted acid sites, and the band at $1446 \mathrm{~cm}^{-1}$ was characteristic Lewis acid sites [23]. It was shown that Bronsted acid and Lewis acid sites co-exists on the surface of the $\beta / \mathrm{Al}-\mathrm{MCM}-41$ and Al-MCM-41. By comparison, the peak intensity of $\beta / \mathrm{Al}-\mathrm{MCM}-41$ is stronger than Al-MCM-41. The relative intensity of Brönsted acid/Lewis acid (B/L) over $\beta /$ Al-MCM-41 and Al-MCM-41 was list, respectively. The results show that Brönsted acid and Lewis acid sites are basically equivalent and the co-action play the key effect on catalytic activity.

\subsection{Catalysis Stability}

The catalytic stability of $\beta / \mathrm{Al}-\mathrm{MCM}-41$ in the esterification of oleic acid was researched, and the results were shown in Figure 3. The catalysts were obtained by vacuum filtration and reused directly after drying without further purification. Relative to the initial conversion, when reuse in the fifth time, the conversion of oleic acid was above $60 \%$ still.

The reused $\beta /$ Al-MCM-41 after 5 times was characterized by XRD and $\mathrm{NH}_{3}$-TPD. Figure 4 shows the XRD patterns of fresh and reused $\beta / \mathrm{Al}-\mathrm{MCM}-41$. Note that there are spectrum peaks at approximately $2 \theta=2^{\circ}$ and $4^{\circ}$, which is characteristic for the hexagonally symmetric MCM-41 mesoporous structure [10]. The peaks of the fresh and reused samples are almost in the same position, which indicates that the catalyst structure was essentially unchanged; the better mesoporous structure still exists.

By comparing the $\mathrm{NH}_{3}$-TPD from Figure 5, the fresh and reused samples have the same profile. By quantitative analysis, the amount of the poor and strong acid were also slightly decreased, maybe this is the reason for the slightly decrease of catalytic activity. The reused catalyst was regenerated by calcinations and then used to catalyze the esterification. The conversion of oleic acid was $70 \%$, which showed that the synthesized catalyst possesses good regeneration performance. 


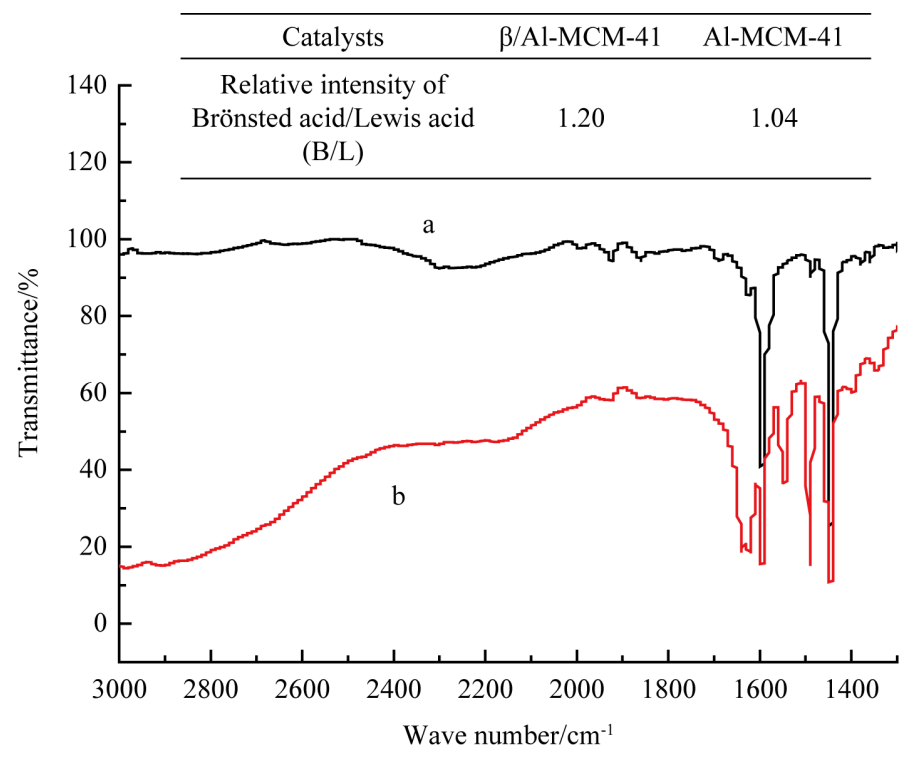

Figure 2. Py-FTIR of $\beta / A l-M C M-41$ and Al-MCM-41. (a) $\beta / A l-M C M-41$, (b) Al-MCM-41.

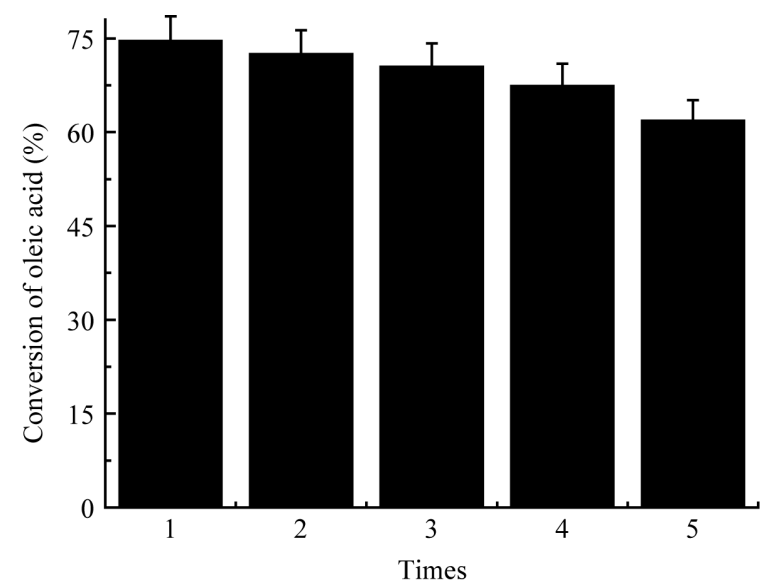

Figure 3. Results on reuse of the catalyst.

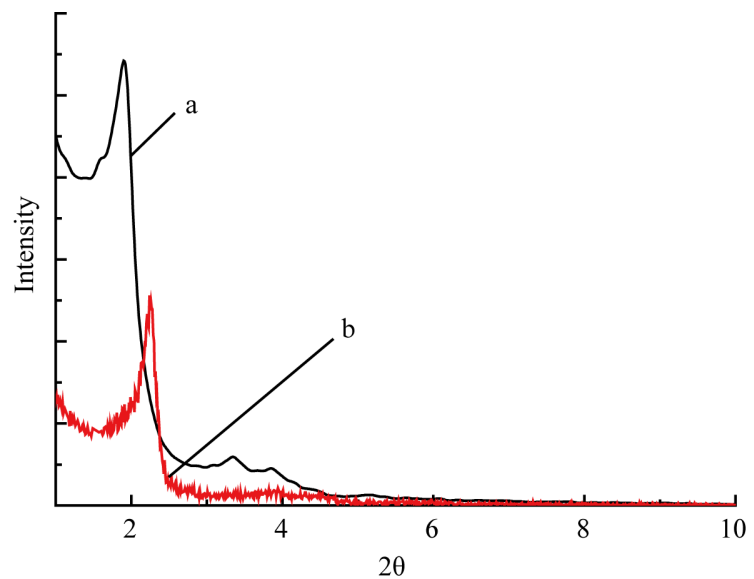

Figure 4. XRD patterns of fresh and reused $\beta / A l-M C M-41$. (a) fresh $\beta / A l-M C M-41$, (b) reused $\beta /$ Al-MCM-41. 


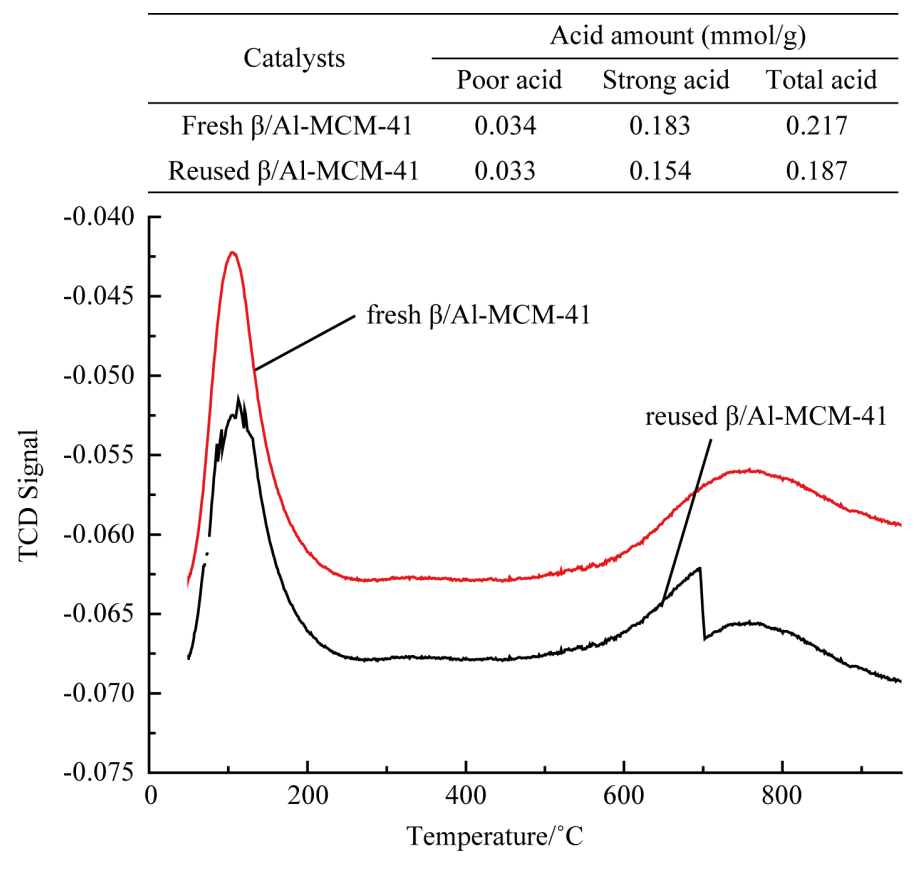

Figure 5. NH3-TPD of fresh and reused $\beta / \mathrm{Al}-\mathrm{MCM}-41$.

\subsection{Reaction Kinetics of Esterification}

In studies of esterification kinetics of oleic acid with methanol, methanol was excessive, the reaction rate can be expressed by Equation (1) [25].

$$
-\frac{\mathrm{d} c_{A}}{\mathrm{~d} t}=k_{1} c_{A}^{n}
$$

where $c_{A}$ represents the concentration of oleic acid at time $t, k_{1}$ represents the rate constant of the reaction.

$$
c_{\mathrm{A}}=c_{\mathrm{A} 0}(1-X)
$$

where $c_{A 0}$ is the initial concentration of oleic acid, $X$ is the conversion of oleic acid. So Equation (1) could be written as follows:

$$
\ln \left(-\frac{\mathrm{d} c_{\mathrm{A}}}{\mathrm{d} t}\right)=\ln k_{1}+n \ln \left[c_{A 0}(1-X)\right]
$$

The effect of reaction temperature on conversion of oleic acid in the presence of $\beta / \mathrm{Al}-\mathrm{MCM}-41$ was showed in Figure 6.

Experimental data were processed by means of computer software Origin 8.0. First calculated instantaneous reaction rate corresponding to different concentration $-\frac{\mathrm{d} c_{A}}{\mathrm{~d} t}$, then calculated $\ln \left(-\frac{\mathrm{d} c_{A}}{\mathrm{~d} t}\right)$ and $\ln c_{A}$. Drawn the relationship between $\ln \left(-\frac{\mathrm{d} c_{A}}{\mathrm{~d} t}\right)$ and $\ln c_{A}$ according to the Equation (3), the slope of the line is the reaction order $n$ and intercept is the reaction rate constant by linear regression.

The linear regression results of the data are showed in Table 2. All of the linear correlative coefficients were higher than 0.99 . According this method, the reaction rate 


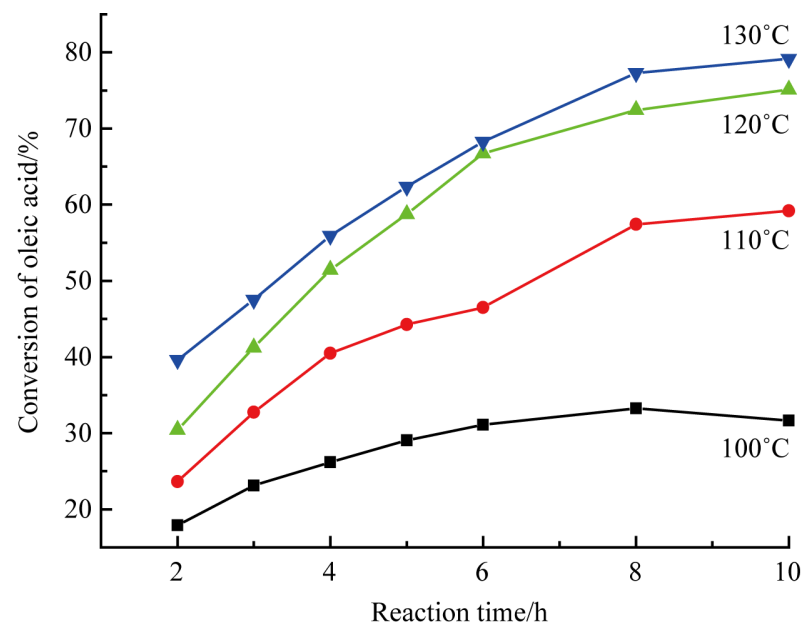

Figure 6. Effect of reaction temperature on reaction rate in the presence of $\beta / \mathrm{Al}-\mathrm{MCM}-41$.

Table 2. Kinetic parameters of esterification at different temperature.

\begin{tabular}{ccc}
\hline Temperature $/{ }^{\circ} \mathrm{C}$ & $k_{1}$ & $n$ \\
\hline 130 & 0.275 & 1.77 \\
120 & 0.226 & 1.751 \\
110 & 0.150 & 2.01 \\
100 & 0.0837 & 2.35 \\
Average value & & 1.97 \\
\hline
\end{tabular}

constant increased with the temperature arising. The average reaction order $n$ was 1.97 .

According to Arrhenius Equation,

$$
k_{1}=k_{0} \exp \left(-\frac{E_{a}}{R T}\right)
$$

Using the rate constants above, the activation energy $\left(E_{a}\right)$ could be obtained by Equation (5).

$$
\ln k_{1}=\ln k_{0}-\frac{E_{a}}{R T}
$$

where $k_{0}$ is pre-exponential factor, $R$ is the gas constant and $T$ is the temperature in Kelvin. The activation energy for this reaction calculated from the slope of Arrhenius plot shown in Figure 7 was $50.01 \mathrm{~kJ} / \mathrm{mol}$.

\section{Conclusions}

The molecular sieve $\beta / \mathrm{Al}-\mathrm{MCM}-41$ was synthesized successfully using $\beta$ as silicaalumina source. The synthesized $\beta / \mathrm{Al}-\mathrm{MCM}-41$ was firstly used as catalyst in the esterification of oleic acid with short chain alcohols. The results indicated that $\beta / \mathrm{Al}-\mathrm{MCM}-41$ exhibited excellent catalytic activity and stability. 


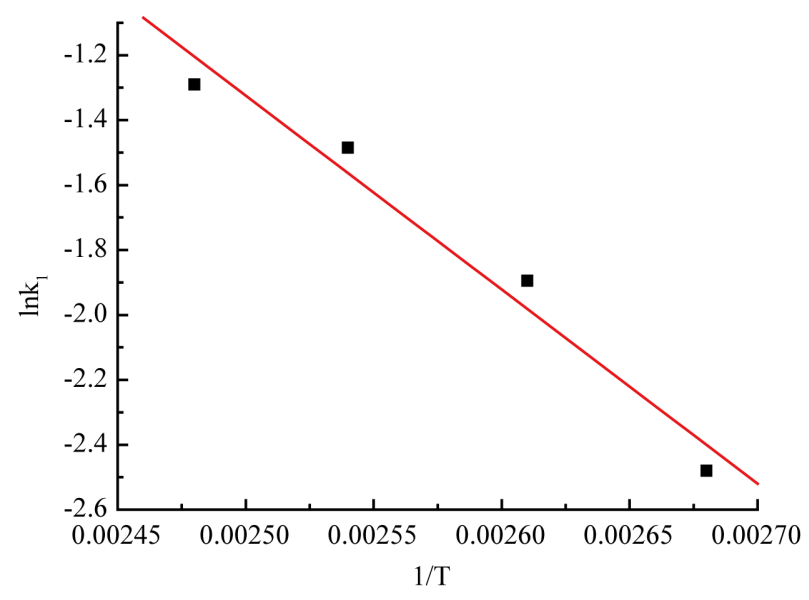

Figure 7. Arrhenius plot of reaction rate constant of esterification.

The kinetics of the reaction was also investigated. The results showed that the average reaction order $n$ of the esterification of oleic acid with methanol was 1.97. The reaction rate is accelerated with the temperature arising. The relationship accorded with the Arrhenius Equation and the activation energy was $50.01 \mathrm{~kJ} / \mathrm{mol}$.

\section{Acknowledgements}

This research was supported by The Taishan Scholar Program of Shandong and Natural Science Foundation of China (31570573).

\section{References}

[1] Zhang Y., Dube, M.A., Mclean, D.D. and Kates, M. (2003) Biodiesel Production from Waste Cooking Oil: 1. Process Design and Technological Assessment. Bioresource Technology, 89, 1-16. http://dx.doi.org/10.1016/S0960-8524(03)00040-3

[2] Bagly, S.T., Gratz, L.D., Johnson, J.H. and Mcdonald, J.F. (1998) Effect of an Oxidation Catalytic Converter and a Biodiesel on the Chemical, Mutagenic and Particle Size Characteristics of Emissions from a Diesel Engine. Environmental Science \& Technology, 32, 11831191. http://dx.doi.org/10.1021/es970224q

[3] Jiang, J.C., Yang, K.H. and Nie, X.A. (2004) Research and Application of Biodiesel. Energy Research and Utilization, 5, 22-25.

[4] Zhou, S., Chen, Y. and Wang, Y.H. (2015) Research and Application of Biodiesel. China Chemical Trade, 5, 47-49.

[5] An, W.J., Xu, D.P. and Wang, H.J. (2005) Chemical Production Methods of the Biodiesel Fuel. Cereals and Oils, 7, 3-6.

[6] Vieville, C., Mouloungui, Z. and Gaset, A. (1993) Esterificaton of Oleic Acid by Methanol Catalyzed by p-Toluenesulfoic Acid and the Cation-Exchange Resins K241 and K1481 in Supercritical Carbon Dioxide. Industrial \& Engineering Chemistry Research, 32, 2065-2068. http://dx.doi.org/10.1021/ie00021a031

[7] Harmer, M.A., Sun, Q. and Farneth, W.E. (1996) High-Surface-Area Nafion Resin/Silica Nanocomposites-A New Class of Solid Acidcatalyst. Journal of the American Oil Chemists' Society, 118, 7708-7715. 


\section{http://dx.doi.org/10.1021/ja9541950}

[8] Wim, D.B., Dirk, E.D. and Wim, M.V. (1999) Mesoporous Sulfonic Acids as Selective Heterogeneous Catalysts for the Synthesis of Monoglycerides. Journal of Catalysis, 182, 156164. http://dx.doi.org/10.1006/jcat.1998.2353

[9] Rohan, D., Canaff, C. and Guisnet, M. (1998) Acetylation of Anisole by Acetic Anhydride over a HBEA Zeolites-Origin of Deactivation of the Catalyst. Journal of Catalysis, 177, 296305. http://dx.doi.org/10.1006/jcat.1998.2108

[10] Beck, J.C., Vartuli, J.C., Roth, W.J., Leonowicz, M.E., Kresge, C.T., Schmitt, K.D., Chu, C.T.W., Olson, D.H. and Sheppard, E.W. (1992) A New Family of Mesoporous Molecular Sieves Prepared with Liquid Crystal Templates. Journal of the American Chemical Society, 114, 10834-10843. http://dx.doi.org/10.1021/ja00053a020

[11] Kresge, C.T., Leonowicz, M.E., Roth, W.J., Vartuli, J.C. and Beck, J.S. (1992) Ordered Mesoporous Molecular Sieves Synthesized by a Liquid-Crystaltemplate Mechanism. Nature, 359, 710-712. http://dx.doi.org/10.1038/359710a0

[12] Karlsson, A., Stocker, M. and Schmidt, R. (1999) Composites of Micro- and Mesoporous Materials: Simultaneous Syntheses of MFI/MCM-41 Like Phases by a Mixed Template Approach. Microporous and Mesoporous Materials, 27, 181-192.

http://dx.doi.org/10.1016/S1387-1811(98)00252-2

[13] Huang, L.M., Guo, W.P., Deng, P., Xue, Z.Y. and Li, Q.Z. (2000) Investigation of Synthesizing MCM-41/ZSM-5 Composites. The Journal of Physical Chemistry B, 104, 2817-2823. http://dx.doi.org/10.1021/jp990861y

[14] Zhang, H.J. and Li, Y.D. (2008) Preparation and Characterization of Beta/MCM-41 Composite Zeolite with a Stepwise-Distributed Pore Structure. Powder Technology, 183, 73-78. http://dx.doi.org/10.1016/j.powtec.2007.11.013

[15] Jiang, T.S., Qi, L.W., Ji, M.R., Ding, H.H., Li, Y.H., Tao, Z.F. and Zhao, Q. (2012) Characterization of Y/MCM-41 Composite Molecular Sieve with High Stability from Kaolin and Its Catalytic Property. Applied Clay Science, 7, 32-40. http://dx.doi.org/10.1016/j.clay.2012.04.016

[16] Shen, Y. and Lu, A.C. (2012) Preparation and Characterization of Mixed Matrix Membranes Based on PVDF and Three Inorganic Fillers (Fumed Nonporous Silica, Zeolite 4A and Mesoporous MCM-41) for Gas Separation. Chemical Engineering Journal, 192, 201-210. http://dx.doi.org/10.1016/j.cej.2012.03.066

[17] Guo, W.P., Huang, L.M., Deng, P., Xue, Z.Y. and Li, Q.Z. (2001) Characterization of Beta/MCM-41 Composite Molecular Sieve Compared with the Mechanical Mixture. Microporous and Mesoporous Materials, 4, 427-434. http://dx.doi.org/10.1016/S1387-1811(01)00217-7

[18] Ooi, Y.S., Zakaria, R., Mohamed, A.R. and Bhatia, S. (2004) Synthesis of Composite Material MCM-41/Beta and Its Catalytic Performance in Waste Used Palm Oil Cracking. Applied Catalysis A: General, 274, 15-23. http://dx.doi.org/10.1016/j.apcata.2004.05.011

[19] Chang, Y.G., Zhang, Y., Wang, X.L. and Lian, P.Y. (2006) Synthesis of $\beta /$ Al-MCM-41 and Its Catalytic Performance in Alkylation. Industrial Catalysis, 14, 13-17.

[20] Ji, X.F., Qin, Z.F., Dong, M., Wang, G.F. and Wang, J.G. (2008) Acylation of Anisole with Acetic Anhydride over H $\beta /$ MCM-41 Composite Molecular Sieves. Journal of Fuel Chemistry and Technology, 36, 621-624.

[21] Javadian, H. and Taghavi, M. (2014) Application of Novel Polypyrrole/Thiol-Functionalized Zeolite Beta/MCM-41 Type Mesoporous Silica Nanocomposite for Adsorption of $\mathrm{Hg}^{2+}$ from Aqueous Solution and Industrial Wastewater: Kinetic, Isotherm and Thermodynamic Stu- 
dies. Applied Surface Science, 15, 487-494.

http://dx.doi.org/10.1016/j.apsusc.2013.11.020

[22] Kumar, N., Arvela, P.M., Ylasalmi, T., Villegas, J., Heikkila, T., Leino, A.R., Kordas, K., Salmi, T. and Murzin, D. (2012) Dimerization of 1-Butene in Liquid Phase Reaction: Influence of Structure, Pore Size and Acidity of Beta Zeolite and MCM-41 Mesoporous Material. Microporous and Mesoporous Materials, 1, 127-134.

http://dx.doi.org/10.1016/j.micromeso.2011.05.032

[23] Cativiela, C., Figueras, F., Fraile, J.M., Garcia, J.I., Mayoral, J.A., Menorval, L.C. and Pires, E. (1993) Comparison of the Catalytic Properties of Protonic Zeolites and Exchanged Clays for Diels-Alder Synthesis. Applied Catalysis A: General, 101, 253-267.

http://dx.doi.org/10.1016/0926-860X(93)80273-S

[24] Dimitrova, R., Gunduz, G. and Spassova, M. (2006) A Comparative Study on the Structural and Catalytic Properties of Zeolites Type ZSM-5, Mordenite, Beta and MCM-41. Journal of Molecular Catalysis A: Chemical, 243, 17-23.

http://dx.doi.org/10.1016/j.molcata.2005.08.015

[25] Song, C.C., Qi, Y.Q., Deng, T.S., Hou, X.L. and Qin, Z.F. (2010) Kinetic Model for the Esterification of Oleic Acid Catalyzed by Zinc Acetate in Subcritical Methanol. Renewable Energy, 35, 625-628. http://dx.doi.org/10.1016/j.renene.2009.08.004.

\section{Submit or recommend next manuscript to SCIRP and we will provide best service} for you:

Accepting pre-submission inquiries through Email, Facebook, LinkedIn, Twitter, etc. A wide selection of journals (inclusive of 9 subjects, more than 200 journals)

Providing 24-hour high-quality service

User-friendly online submission system

Fair and swift peer-review system

Efficient typesetting and proofreading procedure

Display of the result of downloads and visits, as well as the number of cited articles Maximum dissemination of your research work

Submit your manuscript at: http://papersubmission.scirp.org/ 